\title{
No coração do Brasil, uma capital saudável - a participação dos médicos \\ e sanitaristas na construção de Brasília (1956-1960)
}

\author{
In the heart of Brazil, a \\ healthy capital - the \\ participation of doctors and \\ sanitarists in the construction \\ of Brasília (1956-1960)*
}

\section{Tamara Rangel Vieira}

Doutoranda do Programa de Pós-Graduação da Casa de Oswaldo Cruz/Fundação Oswaldo Cruz

Rua Visconde de Ouro Preto, 71/202

22250-180 - Rio de Janeiro - RJ - Brasil

tamararangel@yahoo.com.br

Recebido para publicação em agosto de 2008. Aprovado para publicação em janeiro de 2009.
VIEIRA, Tamara R. No coração do Brasil, uma capital saudável - a participação dos médicos e sanitaristas na construção de Brasília (1956-1960). História, Ciências, Saúde - Manguinhos. Rio de Janeiro, v.16, supl.1, jul. 2009, p.289-312.

\section{Resumo}

Projetada como expressão do arrojo e da modernidade de uma época, Brasília não poderia prescindir de um planejamento que considerasse as condições do sítio onde seria instalada, no interior do país. Construída em região historicamente associada ao isolamento, à pobreza e a doenças, a nova capital demandou a participação de médicos e sanitaristas desde o início das obras, visando garantir condições de salubridade. Ao vislumbrar a oportunidade de ampliar seu espaço de atuação, até então restrito ao interior, os médicos goianos se destacaram nesse processo, do qual se ressaltam os anseios da classe manifestados no periódico editado por sua associação e sua ampla mobilidade e atualização, a contrariar concepções comuns acerca dos médicos do interior.

Palavras-chave: história da medicina; medicina goiana; Brasil Central; Brasília.

\section{Abstract}

Projected as an expression of the daring and modernity of an age, Brasília could not overlook planning that considered the conditions where it would be located in the interior of Brazil. Constructed in a region historically associated with isolation, poverty and diseases, the new capital required the participation of doctors and sanitarists from the very beginning of construction to ensure healthy conditions. Seeing the opportunity to expand their sphere of action, until then restricted to the interior, doctors from Goiás stood out in this process, highlighted by concerns of the profession manifested in the periodical published by its association and their extensive mobility and modern practice, contradicting the common conceptions regarding doctors in the interior.

Keywords: History of medicine; Goian medicine; Central Brazil; Brasília. 
$\mathrm{N}$ o âmbito político nacional, os anos 50 são marcados pela ascensão conturbada de Juscelino Kubitschek de Oliveira à Presidência da República. Com ênfase na máxima dos "cinquenta anos de progresso em cinco anos de governo", o presidente eleito lançou mão de um programa de metas que visava modernizar o Brasil através da aceleração e do aprofundamento do desenvolvimento. Incluída apenas posteriormente em seu programa, a construção de Brasília foi o grande símbolo de seu governo. Em um contexto motivado pelas ideias de modernização, industrialização e urbanização, no auge do desenvolvimentismo e do 'otimismo sanitário', o presidente decidiu concretizar o preceito constitucional tantas vezes adiado e erguer a nova capital federal no interior do país, em região historicamente associada ao atraso, ao isolamento, à pobreza e à doença.

Para essa tarefa contou com o trabalho de médicos e sanitaristas, responsáveis pelo saneamento da região e pela assistência médica aos trabalhadores recém-chegados, cuja vinda ameaçava trazer consigo muitas doenças. Construída para simbolizar o salto econômico e social dado pelo país, Brasília não poderia estar ameaçada por nenhuma enfermidade, pois isso poderia minar o desejo de que fosse reconhecida, acima de tudo, como uma capital moderna.

Destaco neste artigo o papel dos médicos goianos na manutenção da higidez do local onde se construía a nova cidade, sempre dispostos a colaborar nos trabalhos relacionados à transferência da capital federal. A ênfase aqui conferida à participação de Goiás, no que se refere à viabilização da meta mudancista, se deve à sua presença durante todo o processo de transferência da capital, desde o início do século XX. Embora a concretização dessa ideia apareça como a realização de um imperativo nacional, que havia séculos requeria a localização da capital federal no coração do Brasil, é possível perceber, nas fontes, o papel ativo das elites regionais goianas na defesa do projeto. Assim, em todos os momentos em que a questão era retomada pelo governo, é possível acompanhar o empenho dessas elites em levar a nova capital federal para o Planalto Central goiano - região demarcada desde o final do século XIX pela Comissão Cruls - seja organizando um periódico que propagandeava os benefícios da região, ou estabelecendo decretos que facilitassem a mudança.

Acompanhando a circulação das elites goianas, em especial a dos médicos, penso ser possível compreender a forma muito particular em que se deu seu apoio ao empreendimento. Ressaltando a dimensão regional de um projeto nacional, este artigo enfatiza o impacto da construção de Brasília sobre a conformação de uma identidade médica local, que se valeria dos benefícios gerados pela mudança da capital para se destacar no seio de seu próprio campo profissional. A intensa atuação nas áreas interioranas do país, contrariando a ideia de que os médicos dessas regióes seriam atrasados e se submeteriam ao isolamento imposto pelo meio, trazem à tona uma outra concepção de sertão, capaz de redefinir sobre outras bases a ideia do Brasil como 'imenso hospital'.

Apesar do recorte temporal aqui privilegiado, cabe situar em perspectiva histórica as representações acerca do interior do Brasil, com ênfase naquelas relacionadas à transferência da capital do litoral para o sertão. Assim, a primeira parte deste artigo constitui uma síntese das primeiras manifestações em torno da interiorização da capital, no período que se estende de fins do século XIX até o início do século XX, tomando-se por base documentos 
tais como um opúsculo produzido por Francisco Varnhagen e os relatórios produzidos pela Comissão Cruls e pelos médicos sanitaristas Arthur Neiva e Belisário Penna.

A análise das fontes permite perceber as diferentes visões acerca dos sertões do Brasil, perpassadas por um olhar calcado nas concepções médicas de cada período, assim como relacioná-las com os momentos de inflexão pelos quais passou a questão da transferência da capital até os anos 30. Notam-se a configuração de uma dicotomia entre litoral e interior e uma preocupação com a salubridade e clima do Planalto Central, a qual persistirá nos estudos empreendidos na região pelas comissões organizadas nas décadas de 1940 e 1950, segundo mostram os relatórios e artigos de periódicos em que os trabalhos dessas comissões foram debatidos. Destaca-se também a participação ativa dos goianos na propaganda favorável à mudança, refletida nas páginas do periódico Informação Goiana, e na sua mobilização junto a políticos e membros das comissões de estudos, com o propósito de convencê-los sobre os benefícios advindos, para a nação, se para aquela região - e não para o Triângulo Mineiro - fosse levada a capital.

Na segunda seção do artigo enfatizo as atividades das comissões de estudos organizadas pelo governo federal nos anos 50, antes da construção de Brasília, com base em seus relatórios. Neles observa-se, mais uma vez, a importância atribuída à salubridade e ao clima nos trabalhos desenvolvidos, bem como o empenho dos goianos que participaram das comissões em levar a capital para o Planalto Central goiano. O significado da construção de Brasília durante o governo de Juscelino Kubitschek aparece associado às relações entre retórica desenvolvimentista e o combate às 'doenças de massa', sintetizadas no seu Programa de Saúde Pública, de 1955, e na criação, em 1956, de um departamento exclusivo para tratar das endemias rurais.

A última seção deste estudo aborda o papel de médicos e sanitaristas durante a construção da capital. Com base em depoimentos orais e nos artigos da Revista Goiana de Medicina, a intenção é avaliar a participação efetiva, nessa etapa, dos profissionais que, vinculados ao Ministério da Saúde ou provenientes do interior, chegaram atraídos pelas oportunidades abertas na edificação da futura cidade. A ênfase recai sobre o trabalho que desenvolveram, as relações entre as instituições de saúde que lá atuavam, as principais doenças que acometiam os candangos, suas impressões a respeito do interior do Brasil e da nova capital e o que ela representava tanto para aquela parte do país como para a medicina local. Em síntese, ressalta-se a importância da mobilização da elite médica goiana em prol da concretização do projeto de transferência da capital federal e sua repercussão sobre o próprio círculo médico goiano. 


\title{
O Brasil Central em perspectiva histórica: de um quadro impressionista à imagem em preto e branco
}

\author{
No princípio era o ermo \\ Eram antigas solidões sem mágoa. \\ O altiplano, o infinito descampado \\ No princípio era o agreste: \\ O céu azul, a terra vermelho-pungente \\ E o verde triste do cerrado. \\ Eram antigas solidões banhadas \\ De mansos rios inocentes \\ Por entre as matas recortadas \\ Não havia ninguém. \\ (Vinícius de Moraes e Antônio Carlos Jobim, \\ Brasília, Sinfonia da Alvorada)
}

O texto em epígrafe compõe o início da Sinfonia da Alvorada, composta para homenagear a nova capital federal, inaugurada em 21 de abril de 1960. Assim como os versos insinuam, Brasília é considerada uma 'flor no deserto', mote aliás comum na fala de muitos autores, e paráfrase da expressão usada por Roland Corbisier (1960) em Brasília e o desenvolvimento nacional, texto bastante conhecido, no qual o intelectual isebiano relaciona a construção da nova capital a um novo impulso de desenvolvimento do país. Um empreendimento construído em meio à natureza monótona do cerrado, em uma região esquecida pelos brasileiros, em um local onde "não havia ninguém". Tal imagem do Brasil Central, fixada no imaginário nacional desde séculos, funcionaria como um elemento motivador e galvanizador de forças em prol da concretização do projeto mudancista, figurando em vários momentos na fala do próprio Juscelino Kubitschek. Contrapondo-se ao litoral, o interior do país era considerado uma região inóspita, isolada, conformando uma paisagem contrastante com a realidade urbana e moderna das cidades litorâneas. Desse modo, para aqueles que eram favoráveis à ideia, a interiorização da capital se fazia necessária, e sua localização na região central do Brasil funcionaria como um grande polo de atração e fixação de pessoas, promoveria o povoamento do 'deserto' e, consequentemente, garantiria a tão propagada integração nacional.

Conforme nos aproximamos dessa região do Brasil e nos distanciamos no tempo, a imagem de isolamento e vazio, associada à parte mais central do país nos anos 50, ganha outros e múltiplos significados. De acordo com o período analisado, o interior do país pode passar do 'paraíso', região onde tudo era melhor e existia em abundância, ao 'inferno', caracterizado pelo atraso, pela miséria e por incontáveis doenças. Essas diferentes concepções, que deixaram suas marcas nas representações sobre o Brasil Central, também interferiram na viabilização do empreendimento mudancista que passou a constar nos planos de governo a partir da Constituição de 1891. Desde então o projeto passaria por vários momentos de inflexão, e de acordo com a época ora se mostrava promissor, ora inviável ou era simplesmente ignorado. O mote da integração nacional, no entanto, era sempre mobilizado quando o governo se mostrava disposto a retomar a ideia, e a organização de comissões de estudos representava um primeiro passo nessa direção. 
Entre o final do século XIX e meados do século XX, quatro foram as comissões organizadas pelo governo com o objetivo de desenvolver estudos sobre as condições do Planalto Central e escolher, em face de sua imensidão, o local mais adequado para receber a nova capital. Entre os pontos que importava analisar, duas questões não saíam da pauta de preocupações: a salubridade e o clima da região. A importância desses fatores, condições principais a serem satisfeitas pela região escolhida, é demonstrada inclusive pela sua inclusão no artigo 1ํㅡㄹ da lei 1803, promulgada pelo presidente Getúlio Vargas em 1953. De acordo com essa lei, que autorizava o poder executivo a realizar estudos definitivos para localização da nova capital, alguns pontos deveriam ser levados em conta, figurando no topo da lista as condições sanitárias e climáticas da região. Esse tipo de preocupação demandava incluir, nas comissões, profissionais que pudessem auxiliar nesse certame, tais como médicos, sanitaristas, higienistas, climatologistas e geógrafos, sobre os quais recaía a responsabilidade de encontrar um local livre de qualquer doença e que fosse climaticamente agradável.

A preocupação com o clima e a salubridade, presente inclusive no momento da construção de Brasília, guarda estreita relação com aspectos que chamaram a atenção daqueles que primeiro viajaram ao Planalto Central e o sugeriram como o local mais adequado para abrigar a nova capital, ainda no século XIX. Seus olhares estavam embasados por uma perspectiva que relacionava as ideias de 'civilização' - condição a qual o Brasil deveria almejar - às de higiene e salubridade, as quais, por sua vez, estavam associadas às condições climáticas. Tal é o caso, por exemplo, de Francisco Adolfo Varnhagen, que viajou ao interior do país e deixou suas impressões registradas em $A$ questão da capital: marítima ou no interior?, publicada em 1877, e das impressões do médico higienista da Comissão Exploradora do Planalto Central do Brasil ${ }^{1}$, Antonio Martins de Azevedo Pimentel, registradas no Relatório Cruls, publicado em 1894. Embora esses documentos apresentem aspectos característicos do tempo de cada um, ambos se inserem no movimento de valorização do interior do Brasil. A exaltação das inúmeras qualidades dos sertões do país - natureza exuberante, clima aprazível, ambiente salubre e quase desabitado - constitui, pode-se dizer, a marca registrada dos relatos e demonstra o engajamento de seus autores a um projeto nacional específico: demonstrar a viabilidade de erigir uma civilização nos trópicos. Assim, partindo de assertivas de ordem médico-sanitária, calcadas principalmente no paradigma médico-ambientalista ${ }^{2}$, o apelo em torno da necessidade de transferir a capital ganhava crédito, associando de uma só vez a necessidade de integração dessas regiões ao país e a busca por uma imagem mais 'civilizada', como chaves para a efetiva consolidação da unidade nacional (Varnhagen, 1877; Rosas, 1996; Cruls, 2003).

$\mathrm{O}$ primeiro indicador de mudança quanto à imagem otimista dos sertões brasileiros veio com a publicação, em 1902, da obra Os sertões (Cunha, 1997). A percepção diferenciada de Euclides da Cunha sobre a região, a revelar as condições precárias, de isolamento e abandono em que viviam suas populações, estimulou nova reflexão em torno da sociedade brasileira e contribuiu para matizar o cenário divulgado por Varnhagen e pela Comissão Cruls (Oliveira, 2002; Lima, 1999). No entanto o contraste maior seria sentido após a publicação do relatório escrito pelos médicos-sanitaristas Arthur Neiva e Belisário Penna, por ocasião de viagem realizada em 1912 ao interior do país (Neiva, Penna, 1999; Lima, 2003; Lima, Hochman, 1996, 2000, 2004). 
Sob os auspícios do Instituto Oswaldo Cruz e a serviço da Inspetoria de Obras Contra as Secas, Neiva e Penna partiram em direção a regiões localizadas ao norte da Bahia, sudoeste de Pernambuco, sul do Piauí e norte a sul de Goiás, com o objetivo de estudá-las e avaliar a possibilidade de construção de açudes pelo governo federal. Suas impressões de viagem ficaram registradas em um relatório atualmente considerado "um dos mais expressivos e influentes documentos na gênese da imaginação social sobre o Brasil" (Lima, 2003, p.212).

Entre os aspectos mais contrastantes com as impressões anteriormente deixadas por Varnhagen e pela Comissão Cruls, destacam-se aqueles relacionados às patologias encontradas e à miséria em que vivia o povo. Ao contrário da imagem positiva que se tinha até então, Neiva e Penna apresentaram aos brasileiros um sertão completamente abandonado pelo poder público, isolado com relação ao litoral e assolado pela pobreza e por incontáveis doenças. O impacto de sua divulgação sobre a opinião pública, no contexto das expectativas geradas pela 1ํㅡ Guerra Mundial (1914-1918), mobilizou intelectuais e políticos a pensar e buscar uma solução para tal estado de coisas. ${ }^{3} \mathrm{O}$ médico sanitarista Miguel Pereira foi autor de uma das imagens mais marcantes desse período: "fora do Rio ou de São Paulo, capitais mais ou menos saneadas, e de algumas outras cidades em que a previdência superintende a higiene, o Brasil é ainda um imenso hospital" (Pereira, 1922, p.7). A força retórica dessa frase, proferida em um discurso, repercutiu nacionalmente e transcendeu gerações, permanecendo no imaginário nacional durante muito tempo, a ponto de ser possível identificá-la ainda no contexto da construção de Brasília nos anos $50 .{ }^{4}$

Com repercussões negativas sobre o projeto de interiorização da capital federal, o relatório de Neiva e Penna foi alvo de críticas por parte sobretudo dos goianos, que se sentiram injustiçados pelas impressões fatalistas expressas no documento. Descontentes com a imagem que a eles ficou fortemente associada, iniciaram uma campanha em prol da efetivação do preceito constitucional que demandava a mudança da capital. A organização do periódico médico-científico Informação Goiana ${ }^{5}$, que começou a circular em 1917, pode ser considerada uma das medidas mais efetivas, tomadas pelos goianos, a favor da mudança. O periódico tinha como objetivo central divulgar as possibilidades econômicas do Brasil Central e, com isso, convencer sobre os benefícios da transferência da capital para a região. ${ }^{6}$ Nos artigos publicados até 1935, exaltam-se os recursos naturais de Goiás, seu clima e a variedade de sua flora e fauna. Também são desmentidas algumas das informações contidas no relatório dos sanitaristas, como as que se referem a secas e doenças na região, além de contestar-se a afirmação de que o sertanejo seria uma "raça inaproveitável". Esperavam os autores dos artigos rebater a imagem que se havia generalizado e tornar mais bem conhecida a região e suas benesses. Segundo Dominichi Miranda de Sá, em artigo neste mesmo suplemento ("Uma interpretação do Brasil como doença e rotina: a repercussão do relatório médico de Arthur Neiva e Belisário Penna"), a criação da revista Informação Goiana foi a "defesa médica" do Brasil Central, pois contribuiu "de maneira efetiva para reavivar, na agenda política brasileira, a transferência da capital federal para o sertão goiano ...".

No entanto, durante o período em que se deu a circulação do periódico, poucas foram as medidas tomadas pelo governo para concretizar o empreendimento. A despeito da mobilização, principalmente dos goianos, através tanto dessa publicação quanto de projetos apresentados pelos deputados ${ }^{7}$, quase nada foi feito, a não ser a colocação da pedra 
fundamental da futura capital federal no Planalto Central, em 1922. Até a promulgação da Constituição do Brasil de 1934, muito se discutiu sobre o assunto, inclusive durante a elaboração de seu anteprojeto, quando alguns deputados tentaram incluir nele uma emenda definindo a localização da nova capital conforme determinado pela Comissão Cruls, e inserir, nos orçamentos vindouros, verba para cobrir as despesas necessárias à efetivação da medida. No entanto nada saiu do papel.

A Constituição de 1937, decretada com a instauração do Estado Novo, não foi explícita a respeito da questão mudancista. O governo de Getúlio Vargas passou sem que nenhuma medida fosse tomada, apesar da retórica "Marcha rumo ao Oeste", e somente na década de 1940, em meio à redemocratização do país, a questão voltou à tona. Na Assembleia Nacional Constituinte e na imprensa aconteceram manifestações a respeito do preceito constitucional sempre adiado, com opiniões divergindo com relação à transitoriedade da mudança e ao local para onde deveria ser levada a capital (Silveira, 1957; Kubitschek, 2006).

Discutiam-se alternativas à proposta da Comissão Cruls, que variavam entre a localização da capital no Triângulo Mineiro e a recém-inaugurada capital de Goiás, Goiânia. Vale a pena ressaltar a participação, no debate, do então deputado Juscelino Kubitschek, bem como a de outros personagens que se tornariam importantes durante a construção de Brasília, como Lucas Lopes e Israel Pinheiro (Couto, 2006; Bojunga, 2001; Silveira, 1957). Como resultado dessas discussões, o Planalto Central permaneceu na Constituição de 1946 como região privilegiada para os futuros trabalhos demarcatórios, bem como a promessa de que em sessenta dias o presidente nomearia uma comissão de técnicos para proceder aos estudos da localização da nova capital (Brasil, 1946).

Tal como definido na Constituição de 1946, dois meses depois de sua promulgação o presidente Eurico Gaspar Dutra nomeou a Comissão de Estudos Para a Localização da Nova Capital, empossada em novembro daquele ano. Chefiada pelo general Djalma Poli Coelho, a Comissão era composta por 12 técnicos, entre eles engenheiros, agrônomos, geólogos, higienistas, médicos e militares, que se dividiriam entre trabalhos de gabinete e de campo. ${ }^{8}$

Tanto no terceiro volume do Relatório Técnico da nova comissão quanto em alguns artigos publicados em revistas como Boletim Geográfico e Revista Brasileira de Geografia, observa-se não apenas a continuidade de uma imagem dualista da nação - a qual, segundo os defensores da mudança da capital, somente a sua transferência poderia suplantar -, mas também a permanência de aspectos relacionados com a salubridade e o clima da região como critérios relevantes na escolha do melhor sítio para a nova capital. Assim, aspectos topográficos e climáticos apareciam como os de maior peso, uma vez que, escolhido o local, seria "impossível remediar futuramente quaisquer de seus defeitos" (Guimarães, 1949, p.510). A região deveria contar com terrenos vastos e planos, ligeiramente inclinados para facilitar o escoamento das águas e a construção de uma rede de esgotos, bem como para quebrar a monotonia da paisagem. O clima deveria "ser tal que ofereça boas condições de conforto ao organismo humano, sem temperaturas excessivas, demasiada umidade e ventos violentos. Deve garantir boas condições de salubridade, sendo altamente importante que a zona esteja isenta de malária ..." (p.509). Uma paisagem atraente também era considerada relevante, devido à sua "repercussão na psicologia dos habitantes", afinal, tratava-se "de transferir a capital, de um dos sítios mais belos do mundo, o Rio de Janeiro; e um local sem 
atrativos não será aceito com facilidade pela opinião pública ..." (p.511). Outros aspectos foram levados em consideração, como a ocorrência de água em abundância e terrenos propícios à agricultura, porém foram de menor relevância na escolha, uma vez que esses recursos poderiam ser encontrados nos arredores da cidade.

Os resultados dos estudos da Comissão dividiram seus membros entre aqueles que defendiam a localização da nova capital no centro geométrico do país (mais próxima do retângulo demarcado por Cruls) e aqueles que julgavam mais acertada a decisão de levar a capital para o centro demográfico do Brasil (no Triângulo Mineiro). Interessados na transferência da capital para onde ficara definido pela Comissão Cruls, os goianos incluíram na própria Constituição estadual um dispositivo relativo à causa mudancista. ${ }^{9}$ Os deputados goianos esforçavam-se para convencer seus pares de que a melhor solução para o país seria a mudança da capital federal para o seu estado, argumentando com o bem-sucedido exemplo da recém-inaugurada capital estadual (Silveira, 1957). Na Comissão de Estudos, contavam com a representação do engenheiro Jerônimo Coimbra Bueno, eleito em 1947 governador de Goiás - fato, inclusive, que gerou certa polêmica no seio da Comissão, uma vez que os demais membros temiam pela parcialidade de suas opiniões (Brasil, 1948).

Em julho de 1948 ficou decidido, por maioria dos votos, que a capital federal deveria localizar-se no centro geométrico do Brasil, uma região com cerca de $78.000 \mathrm{~km}^{2}$, praticamente despovoada e inexplorada, formada de terras do leste de Goiás, confinando a leste com os estados da Bahia e Minas Gerais e abrangendo, ao sul e parte do oeste, o retângulo demarcado pela Comissão Cruls em 1892 e, ao norte, a Chapada dos Veadeiros (Castro, 1948; v. Figura 1). No entanto, somente após os estudos desenvolvidos por uma nova comissão organizada em 1953, saber-se-ia definitivamente o local onde seria construída a nova capital.

\section{O Brasil não é só hospital: a retórica desenvolvimentista e o lugar da saúde na construção da nova capital}

Os trabalhos da comissão instituída no governo Dutra se desenrolaram no contexto do final da $2^{a}$ Guerra Mundial, marcado por novas possibilidades obtidas com avanços médicocientíficos e com a generalização da ideia de desenvolvimento.

A relevância que as atividades sanitárias e o combate às doenças adquiriu então no Brasil coadunou-se com uma lógica que se consolidaria internacionalmente durante a Guerra: a da importância da saúde como fator de desenvolvimento. Nessa conjuntura os inseticidas, as vacinas e os antibióticos foram alguns dos produtos que contribuíram para o clima de 'otimismo sanitário' que marcou o período. Diante das perspectivas promissoras de solução para incontáveis doenças, a exemplo da malária e da febre amarela, duas das maiores preocupações do governo brasileiro, esse clima repercutiu em toda a sociedade (Lima, Hochman, Fonseca, 2005).

No plano internacional, uma vez que as doenças apareciam como os maiores obstáculos no projeto de promoção do desenvolvimento mundial, discutia-se seu custo econômico e social, seu grau de interferência na produtividade do trabalho e as relações de causalidade entre doença e pobreza. A criação, em 1948, de um órgão de nível internacional para tratar dos problemas sanitários - a Organização Mundial da Saúde - representa bem esse momento 
em que a saúde assumiu uma posição de destaque no cenário mundial. A relação entre saúde e desenvolvimento passou a constar em pronunciamentos e conferências internacionais, concluindo-se que a promoção de medidas de cunho sanitário poderia contribuir para alavancar o desenvolvimento. Nos anos 50 essa relação chegou ao seu ápice, demandando ações efetivas do governo brasileiro na luta contra as endemias rurais, consideradas responsáveis pela baixa produtividade dos trabalhadores do interior e pelo lento crescimento do país (Kropf, 2006; Lima, Hochman, Fonseca, 2005; Moreira, 1998).

Assim, a associação entre saúde e desenvolvimento encontrou ecos no governo de Juscelino Kubitschek (1956-1960). Em seu "Programa de saúde pública", lançado em 1955 durante a campanha eleitoral, nota-se forte associação entre o combate às doenças de massa, a necessidade de elevação dos níveis de vida do trabalhador rural, o soerguimento econômico do interior e os ideais desenvolvimentistas de sua proposta. Entre os temas abordados, figuram principalmente as endemias rurais (doença de Chagas, malária, verminoses, bócio, tracoma etc.), o saneamento básico e a alimentação. Chamam nossa

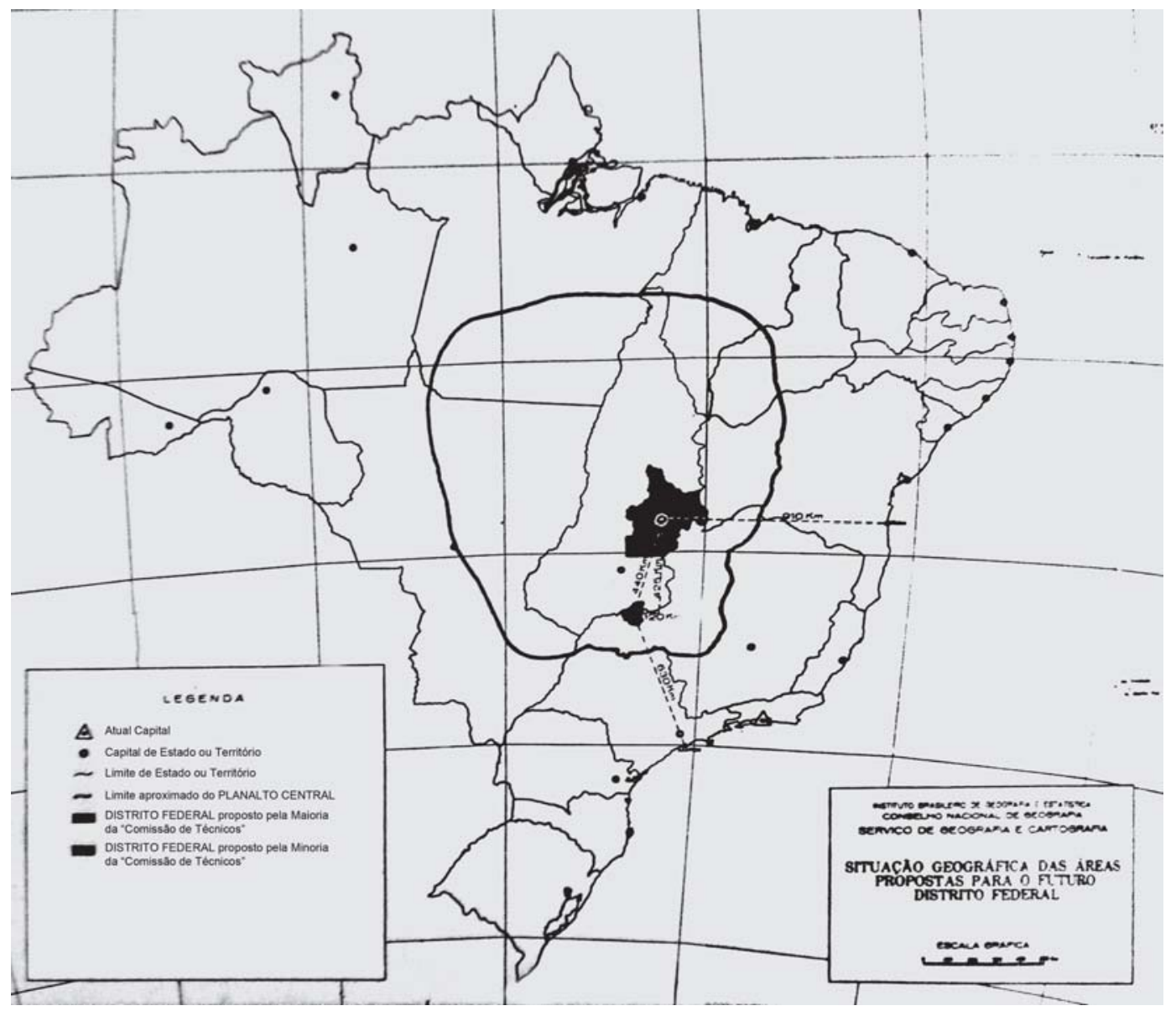

Figura 1: As duas regiões escolhidas pela Comissão de Estudos para a localização da nova capital. A área preenchida, em tamanho maior, refere-se à escolha da maioria dos membros da Comissão e abrange, entre outras regiões, o retângulo demarcado pela Comissão Cruls; a área menor representa a escolhida pela minoria e abrange o Triângulo Mineiro. 
atenção as referências ao trabalho dos sanitaristas do início do século XX e a constante refutação da frase de Miguel Pereira, quanto ao Brasil ser um 'imenso hospital' - já então considerada ultrapassada:

\begin{abstract}
Quando voltarmos os olhos para o nosso homem do interior, não devemos ver só um homem doente. Não existem só doenças e doentes no vasto interior do Brasil. Ao lado das grandes populações enfermas, existe uma grande população de gente sadia e bem disposta, trabalhando com resultado e esperança. Hoje em dia, com as facilidades de transporte, com as grandes estradas e, sobretudo, com o nosso intensíssimo tráfego interno, não se permitem mais atitudes de pessimismo ou negativistas com relação ao próximo futuro do Brasil. Só os que não conhecem o Brasil, vivem arrolhados nas cidades, podem duvidar do povo brasileiro ... (Kubitschek, 1955, p.32).
\end{abstract}

Já não somos mais, esta justiça deve ser feita, o vasto hospital da frase, que se tornou histórica porque verdadeira, da observação clarividente de Miguel Pereira... (p.53).

A construção de Brasília é uma boa oportunidade de perceber como se estabeleceu a relação entre saúde e desenvolvimento. Embora não haja referência explícita à importância dos aspectos higiênicos e sanitários no plano urbanístico desenvolvido por Lúcio Costa (1991), é nítida sua preocupação com o bem-estar dos futuros moradores da cidade, que deveriam desfrutar de um ambiente arborizado e saudável, de amplos espaços de lazer, segurança e conforto. Pode-se então afirmar que no projeto moderno da nova capital federal, além da preocupação com a organização e o planejamento de todos os componentes de uma cidade projetada para tal fim e com a estética monumental dos prédios, estava impressa a expectativa de uma vida mais saudável. Se as cidades podem ser pensadas como expressões de "estágios de modernidade", tal como sugere Helena Bomeny (2002, p.210), Brasília, projetada como expressão do arrojo e da modernidade de uma época, não poderia prescindir de um planejamento que levasse em conta suas condições locais de salubridade, principalmente quando considerada sua localização em região vista como inóspita, isolada, atrasada e doente.

De fato, para levar a cabo o empreendimento, a nova capital contou com a participação ativa dos médicos e sanitaristas, desde o início de sua construção. Responsáveis pela manutenção da salubridade local e pelas atividades de prevenção e educação sanitárias, chegavam com as missões de preparar a região que se tornaria símbolo de um Brasil cônscio de suas riquezas e de combater as mazelas de seu povo. Pouco abordado pelos estudos históricos relativos à transferência da capital federal, o aspecto sanitário também conformava, juntamente com os demais projetos (arquitetônico, urbanístico, educacional etc.), a ideia, bastante difundida pelo governo de Juscelino Kubitschek, de uma capital que espelhasse uma nação plenamente integrada, moderna e desenvolvida. Nesse sentido, as atividades voltadas para o saneamento rural repercutiriam positivamente no plano do governo, favorecendo a concretização de sua grande meta, do mesmo modo que a concretização do secular preceito constitucional aceleraria o desenvolvimento do interior.

A decisão final de levar a capital federal para aquela região específica do Planalto Central não foi, no entanto, fruto do governo de Kubitschek. Decorreu dos trabalhos desenvolvidos pela última comissão de estudos instituída com tal propósito em 1953, no governo de Getúlio Vargas. A Comissão de Localização da Nova Capital Federal ${ }^{10}$, tal como ficou 
conhecida, tinha como presidente o chefe da Casa Militar da Presidência da República general Aguinaldo Caiado de Castro, e seus estudos deveriam ser concluídos no prazo máximo de três anos. Além do clima e da salubridade, condições prioritárias, a região deveria satisfazer outros aspectos: facilidade de abastecimento de água e energia elétrica; facilidade de acesso às vias de transporte terrestres e aéreas; topografia adequada; solo favorável às edificações e existência de materiais de construção; proximidade de terras para cultura; e, por último, paisagem atraente (Brasil, 1953). Para auxiliar a comissão em seus trabalhos, foi contratada a firma de engenharia norte-americana Donald J. Belcher and Associates Incorporated, de cujos estudos resultou a indicação dos cinco sítios mais adequados à construção da nova capital (Brasil, 1957; Silveira, 1957; Couto, 2006; Silva, 2004).

Com a morte de Getúlio Vargas, em agosto de 1954, João de Campos Café Filho nomeou o marechal José Pessoa Cavalcanti de Albuquerque em lugar do general Caiado de Castro na presidência da Comissão, que teve também alguns de seus membros substituídos. ${ }^{11}$ Após confrontar o relatório final da firma norte-americana e as impressões do marechal José Pessoa, que havia visitado a região pessoalmente, a Comissão ponderou sobre as vantagens e desvantagens de cada um dos sítios, diferenciados por cores para facilitar os estudos, decidindo-se pelo de cor castanho, com uma área de $5.850 \mathrm{~km}^{2}$ (Silveira, 1957; Couto, 2006; Silva, 2004). Uma vez definida a localidade, que parecia preencher todos os pré-requisitos estipulados na legislação, principalmente os de ordem climática e sanitária, ela deveria ser declarada de utilidade pública para posterior desapropriação e início dos trabalhos. A tarefa coube ao então governador de Goiás José Ludovico de Almeida, que, atendendo a pedido do marechal José Pessoa, baixou um decreto nesse sentido em 30 de abril de 1955.

No final de dezembro de 1955, a Comissão que havia sido instituída durante o governo Vargas transformou-se, por decreto presidencial, em Comissão de Planejamento da Construção e da Mudança da Capital Federal (Brasil, 1955), e em junho de 1956 passou a ser presidida pelo médico Ernesto Silva ${ }^{12}$, ex-assistente do marechal José Pessoa, que havia pedido demissão do cargo. À frente dos trabalhos a partir de então, entre as medidas tomadas pelo médico estão o lançamento do edital de concurso para o Plano Piloto de Brasília e as negociações com o Departamento Nacional de Endemias Rurais (DNERu), para que fosse designado um sanitarista para estudar as condições de salubridade da região e tomar outras medidas que se fizessem necessárias, como a iodetização do sal para prevenção do bócio, doença muito comum na região (Silva, 2004).

Menos de um ano após sua criação, a Comissão foi extinta e sancionada a lei que autorizava o poder executivo a constituir a Companhia Urbanizadora da Nova Capital do Brasil (Novacap), que seria responsável pelo planejamento e pela execução dos serviços de localização, organização e construção da futura capital federal (Brasil, 1956). O presidente da nova companhia Israel Pinheiro, com o intuito de descentralizar a administração, distribuiu setores de supervisão entre os membros da diretoria Ernesto Silva, Bernardo Sayão e Íris Meinberg.

Para os propósitos deste artigo, importa destacar as atividades do Departamento de Assistência Social e Saúde, que ficou a cargo de Ernesto Silva. O órgão era constituído pelo Departamento de Saúde da Novacap, sob a chefia do médico Jairo de Assis Almeida, por 
um posto do DNERu, sob o comando do médico João Leão da Motta, e por um posto de atendimento emergencial, sob a supervisão do Instituto de Aposentadorias e Pensões dos Industriários (Iapi), que ficou sob a direção do médico recém-formado Edson Porto - o primeiro médico a chegar em Brasília (Silveira, 1957; Couto, 2006; Silva, 2004; v. Figura 2).

\section{A construção de Brasília: os pioneiros da poeira em ação}

Nascido em Araguari, interior de Minas Gerais, Edson Porto chegou ao Rio de Janeiro na década de 1940 para cursar a Faculdade Nacional de Medicina. Após a conclusão de seus estudos, decidiu regressar ao interior em busca de novas oportunidades de trabalho. Optou pela cidade de Goiânia, que na época florescia como capital, e buscou emprego no Hospital Rassi, entrelaçando definitivamente sua trajetória profissional com a história de Brasília, onde chegou em 4 de dezembro de 1956 (Porto, 2006, fita 1, lado A). Esse hospital, construído pelos irmãos Alberto e Luiz Rassi, devido a um contrato firmado com o Iapi, foi responsável pela prestação dos primeiros serviços médicos em Brasília e cabia-lhe montar um posto de atendimento em caráter emergencial. A prestação de assistência em Brasília estava condicionada, no entanto, a um empréstimo requisitado ao Iapi pelo Hospital, para conclusão de suas obras, já que, por conta de dificuldades financeiras, ele funcionava apenas com metade de sua capacidade (Rassi, 2006, fita 2, lado B).

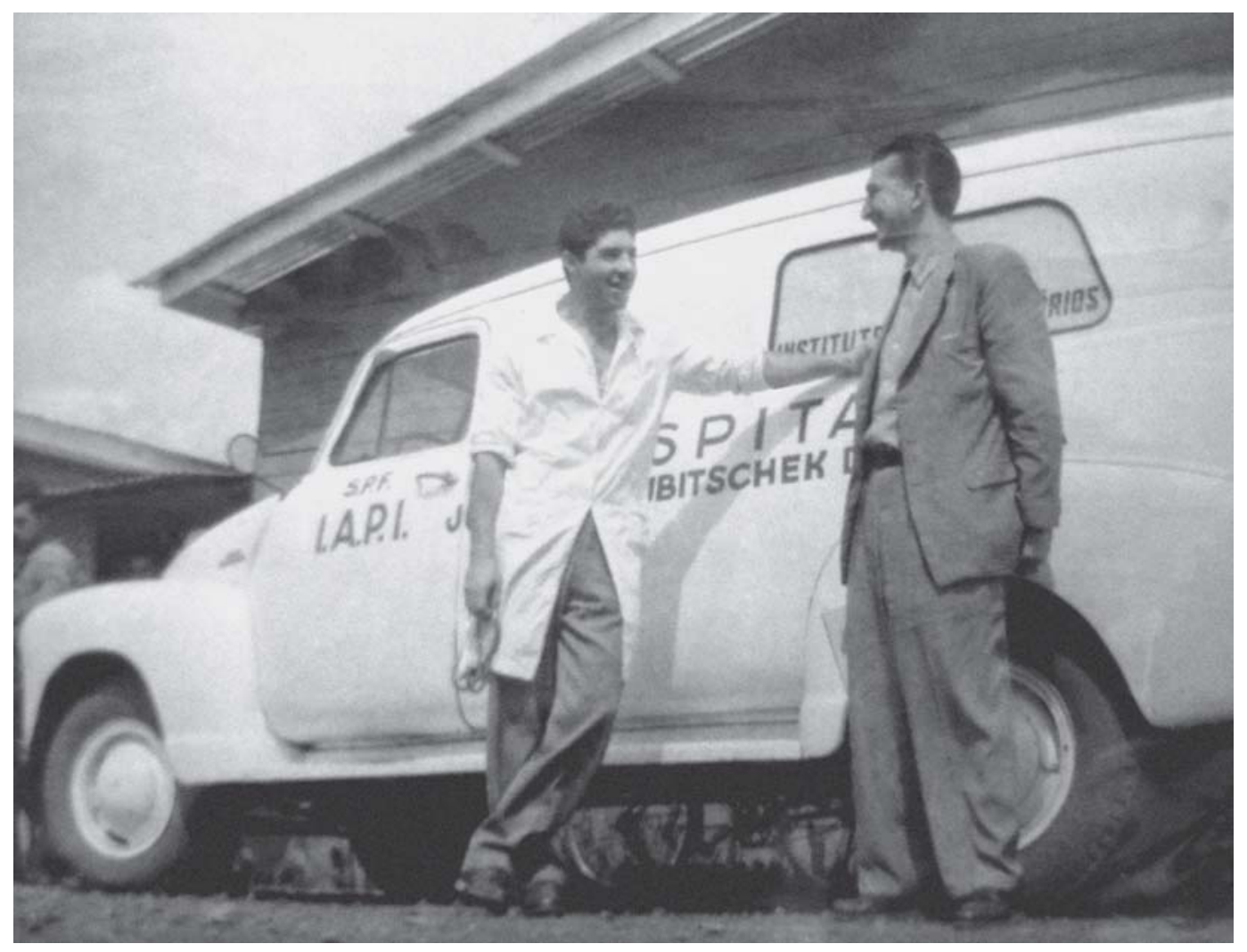

Figura 2: Doutor Edson Porto, de jaleco, e a primeira ambulância de Brasília (Arquivo pessoal de Edson Porto). 
A dificuldade em convencer os funcionários do Hospital a permanecer em Brasília e, por outro lado, o interesse de Edson Porto em montar um consultório de pediatria, fizeram com que o médico propusesse aos irmãos Rassi um acordo: prontificava-se a permanecer em Brasília o tempo que fosse necessário, sem necessidade de rodízio com outros profissionais, contanto que, ao retornar, com o término das obras, seu espaço de atuação estivesse garantido no hospital em Goiânia. Inicialmente o tempo estipulado para a permanência de Porto foi de três meses. No entanto, o empréstimo do Iapi para as obras no Hospital não saiu no prazo previsto, e Edson Porto, que se comprometera a permanecer em Brasília durante as obras, viu-se obrigado a estender um pouco mais sua estadia no canteiro de obras da futura capital federal (Porto, 2006, fita 1, lado B).

No posto médico em que trabalhavam, uma pequena construção de madeira, Edson Porto e um enfermeiro eram responsáveis pelo atendimento inicial aos operários, realizando o exame clínico que permitia aos trabalhadores se cadastrar na Novacap e ganhar a carteira de saúde, sem a qual não podiam ser contratados pelas empresas construtoras. No exame verificavam-se a pressão, o coração e se o paciente possuía doenças crônicas ou agudas. Para os casos de doenças ou acidentes mais graves que necessitassem de internação, o governo de Goiás disponibilizava um avião para levar o paciente até o hospital em Goiânia (Porto, 2006, fita 1, lado B). Esse trabalho assistencial permaneceu sob a responsabilidade de Edson Porto até a instalação do Departamento de Saúde da Novacap, três meses após sua chegada. ${ }^{13} \mathrm{~A}$ partir de então, todos os que chegavam dispostos ao trabalho passariam pela vacinação contra varíola, paratifo e febre amarela e, se necessário, por pesquisas laboratoriais e exames nos Serviço de Tuberculose e de Lepra (Silva, 2004). ${ }^{14}$

O número de trabalhadores multiplicava-se a cada dia no canteiro de obras. Por ser a maioria proveniente de Goiás, Minas Gerais e Nordeste, esses homens ficaram conhecidos como candangos. Ao chegarem, antes de passar pelo Departamento de Saúde, eram encaminhados ao Centro de Assistência e Orientação Profissional, onde eram submetidos à 'higienização' (banho, corte de cabelo e de barba) juntamente com toda família. Depois de realizar todos os exames e receber a carteira de saúde, eram levados à polícia para cadastro e exame psicotécnico, restando ao Instituto Nacional de Imigração e Colonização a sua colocação no trabalho (Brasília..., 1960).

A iniciativa do Departamento de Saúde em submeter todos os trabalhadores que chegavam a exame médico e condicionar o emprego à aquisição da carteira de saúde demonstra preocupação com a possibilidade de esses homens trazerem consigo doenças para uma região considerada livre de qualquer enfermidade. Esta assertiva ficou registrada na Revista Goiana de Medicina, na qual, desde o início de sua circulação, em 1955, foram publicados não apenas os levantamentos epidemiológicos realizados pela circunscrição Goiás do DNERu, mas também artigos de médicos do interior que versavam, entre outros assuntos, sobre o saneamento de Brasília.

A criação de uma revista constava nos planos da Associação Médica de Goiás (AMG) desde a sua fundação pelo médico Luiz Rassi, em 1950, porém isso só se concretizou com a chegada a Goiânia de seu futuro editor, Joffre Marcondes de Rezende ${ }^{15}$, em 1954. Rezende colocou-se imediatamente à disposição para iniciar os trabalhos de produção de um periódico vinculado à Associação, cujos membros eram, sem exceção, adeptos da causa mudancista, 
vista como benéfica para todo o Estado (Rassi, 2006, fita 3, lado B). Esse sentimento refletiase nas páginas da revista, em que se publicavam matérias de médicos associados (de Goiás), assim como de médicos de outros estados, como Minas Gerais, São Paulo e Rio de Janeiro. No entanto, pelo fato de os primeiros serem maioria, considero a revista como porta-voz dos médicos do Brasil Central e de seu otimismo com relação às oportunidades abertas pela interiorização da capital. ${ }^{16}$

Os objetivos da Revista Goiana de Medicina constam no editorial de seu primeiro número, no qual aparecem as pretensões de estabelecer, por meio da revista, um elo entre os médicos do interior de Goiás e sua associação de classe. Através da publicação de trabalhos originais e atuais de todas as clínicas em suas seções, do estabelecimento de um intercâmbio com as revistas congêneres e da divulgação de trabalhos de médicos ilustres de outros estados, visavam seus editores "melhorar sempre o padrão da medicina que se pratica em Goiás, preparando o terreno da nossa futura Faculdade de Medicina ..." (Editorial, 1955, p.1), tema, aliás, assíduo no periódico. Considerada uma obra pioneira pelos médicos que dela participavam, a Revista estava voltada principalmente para as patologias regionais. Apesar de inexpressiva no âmbito nacional, circulava inclusive internacionalmente e significou uma oportunidade, para os médicos do interior, de publicar seus trabalhos, dando inclusive projeção a alguns desses profissionais. ${ }^{17}$

Entre os trabalhos publicados encontram-se os inquéritos epidemiológicos efetuados onde seria estabelecida a nova capital - questão candente para os médicos que atuavam no Brasil Central e que também escreviam no periódico. Tendo o DNERu começado a atuar na região e nas redondezas já em 1956, através de sua circunscrição de Goiás ${ }^{18}$, conforme iam chegando levas de migrantes e trabalhadores apareciam na revista artigos destinados a informar sobre o andamento das atividades. Na maioria das vezes são relatórios bastante técnicos, envolvendo estatísticas e tabelas a abordar inúmeras variáveis, como densidade demográfica, clima, umidade, índice pluviométrico, vegetação e tipos de moradias. Nesses relatórios frequentemente nega-se a existência de algum tipo de enfermidade no local: ainda que o entorno da região demarcada estivesse infestado de moléstias como a febre amarela e a doença de Chagas, o sítio da nova capital permanecia hígido (Carvalho, Verano, 1956; Carvalho, Castro, 1957).

Era obrigação dos médicos encaminhar qualquer caso de doença infecciosa ao DNERu ou ao Departamento de Saúde da Novacap, órgãos responsáveis pela garantia da saúde do trabalhador e pela manutenção da salubridade da região. Esses órgãos também desenvolviam um trabalho de educação sanitária, no qual os cuidados com a saúde eram repassados aos operários inclusive por meio de palestras (Porto, 2006, fita 1, lado B, fita 2, lado A). A atuação conjunta no combate às enfermidades demonstra a boa relação entre os médicos atuantes em Brasília, fossem eles funcionários do governo ou particulares. Um bom exemplo disso é a cooperação dos médicos que primeiro chegaram ao canteiro de obras no trabalho de educação sanitária promovido por órgãos federais: os médicos produziram cartazes com a foto do barbeiro para alertar os trabalhadores, em especial os recém-chegados que se instalavam em barracos, sobre os perigos da infestação do inseto transmissor da doença de Chagas (Ribeiro, 1957). 
Um dos médicos engajados na tarefa de educação sanitária foi Isaac Barreto Ribeiro. Proveniente da Bahia, onde nasceu em 1924, teve uma trajetória marcada pelo trabalho no interior do país. Formou-se em 1948 pela Faculdade de Medicina de Minas Gerais, em Belo Horizonte, e logo seguiu para as cidades de Rio Verde, Anápolis, Oruana e Ceres, onde permaneceu até anunciarem a construção de Brasília (Ribeiro, 2006, fita 1, lado A). A vontade de participar da construção de uma nova cidade, somada à busca por um campo profissional menos competitivo, o levou a fixar-se definitivamente em Brasília a partir de 31 de dezembro de 1956, data em que chegou com sua família ao canteiro de obras (Ribeiro, 2006, fita 3, lado A). Uma vez estabelecido na Cidade Livre ${ }^{19}$, começou a receber os pacientes em seu centro cirúrgico, a maioria operários que erguiam a nova cidade. Segundo o médico, eles chegavam ao ambulatório vitimados por acidentes de trabalho, traumatismos ou fraturas devido a quedas, além dos muitos casos de verminose e anemia. Às vezes traziam consigo maleita ou doença de Chagas, mas essas não eram doenças autóctones, ressalta o médico.

Algum tempo depois, Isaac Ribeiro dividiria seu trabalho no ambulatório da Cidade Livre com o Hospital Juscelino Kubitschek de Oliveira (HJKO), onde começou a trabalhar após sua inauguração, em 6 de julho de 1957 (Figura 3). O Hospital substituiu o pequeno posto médico em que Edson Porto havia iniciado seus trabalhos em Brasília. Localizava-se junto ao Núcleo Bandeirante e tinha como função prestar assistência médica, cirúrgica e odontológica a servidores, operários e particulares (Silva, 2004, p.88). Construído por sugestão de Luiz Rassi, que viajava periodicamente a Brasília para acompanhar os trabalhos de assistência médica sob responsabilidade de seu hospital, sua inauguração oficial aconteceu com a realização de duas cirurgias - uma de bócio e outra de megaesôfago - pelo próprio Rassi. Segundo Edson Porto, era um hospital de madeira, com quarenta leitos e as cadeiras médicas básicas: centro cirúrgico, sala de parto, laboratório e emergência. Contava ainda com um conjunto habitacional onde residiam os médicos com seus familiares (Porto, 2006, fita 2, lado A; v. Figura 4). Nomeado diretor do HJKO, Rassi permaneceu no posto apenas até janeiro de 1958, abandonando-o devido ao não recebimento do prometido empréstimo requisitado ao Iapi para a conclusão das obras de seu hospital em Goiânia (Rassi, 2006, fita 3, lado A). Edson Porto o substituiu no cargo, decidindo-se por permanecer definitivamente em Brasília.

Descendente de família libanesa estabelecida no interior do país nos anos 20, Luiz Rassi saiu de Goiás para cursar, assim como Edson Porto, a Faculdade Nacional de Medicina do Rio de Janeiro. Após formar-se, no final dos anos 40, dirigiu-se para Goiânia, onde seu irmão havia montado uma casa de saúde, e ali fixou residência desde então (Rassi, 2006, fita 1, lado B). Sua relação com Brasília, como já mencionado, se deu a partir do convênio estabelecido com o Iapi. Considerando-se um entusiasta da ideia mudancista, avaliou a situação médica do interior no momento em que se construía a nova capital:

Eu sempre fui entusiasta dos grandes movimentos de desenvolvimento econômico e populacional .... Era um ideal que devia ser perseguido até a sua construção, até o término. Por quê? Desde aquela época, achava que a distribuição de médicos no Brasil estava mal colocada, sempre seguindo o litoral. Porque os médicos não saíam das grandes capitais, ou ficavam nas proximidades das grandes capitais, inclusive em estados mais próximos do litoral, enquanto que o interior era totalmente abandonado à própria sorte ... (Rassi, 2006, fita 2, lado B). 


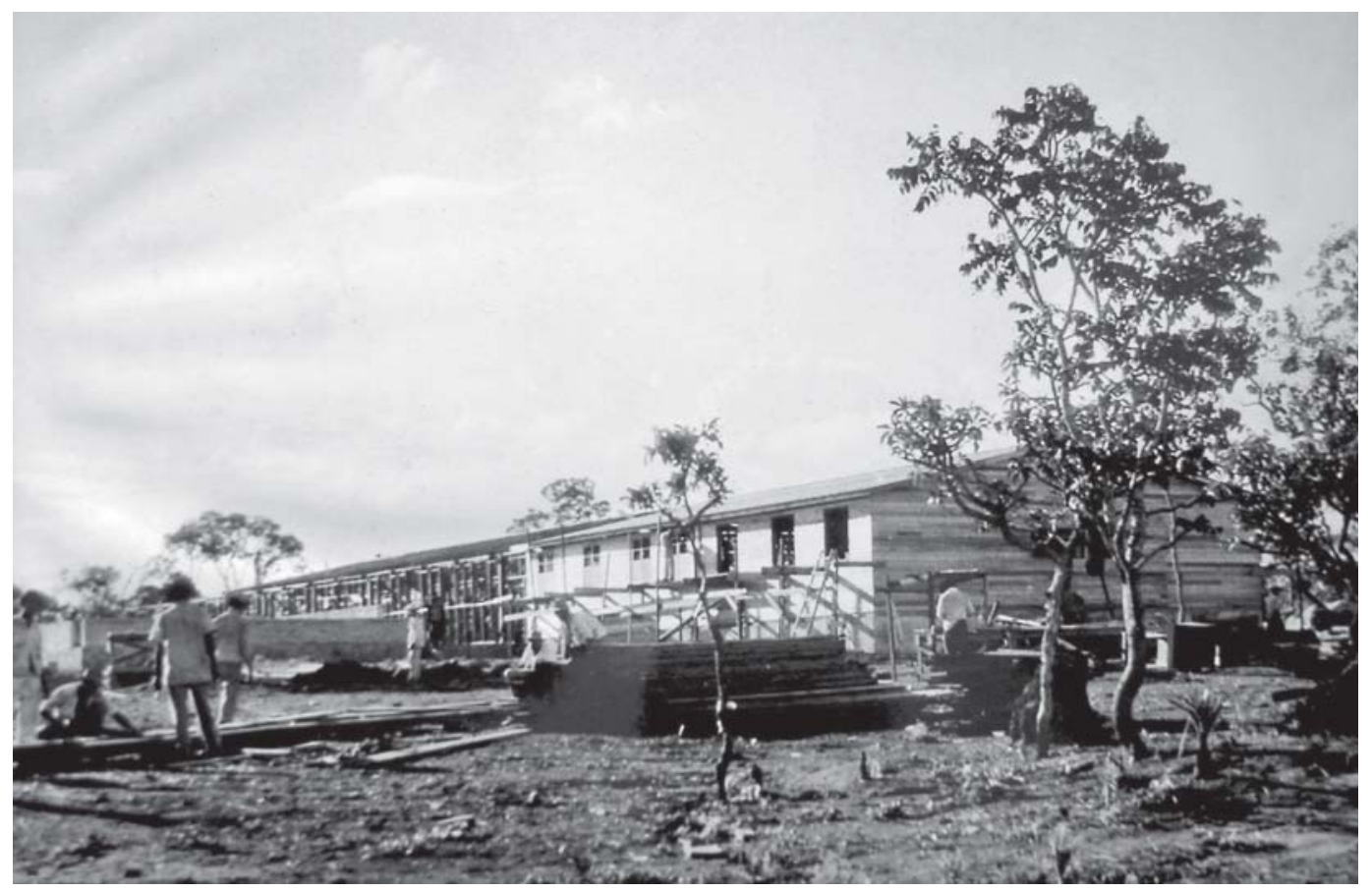

Figura 3: Hospital Juscelino Kubitschek de Oliveira em construção, abril de 1957 (Arquivo pessoal de Edson Porto).

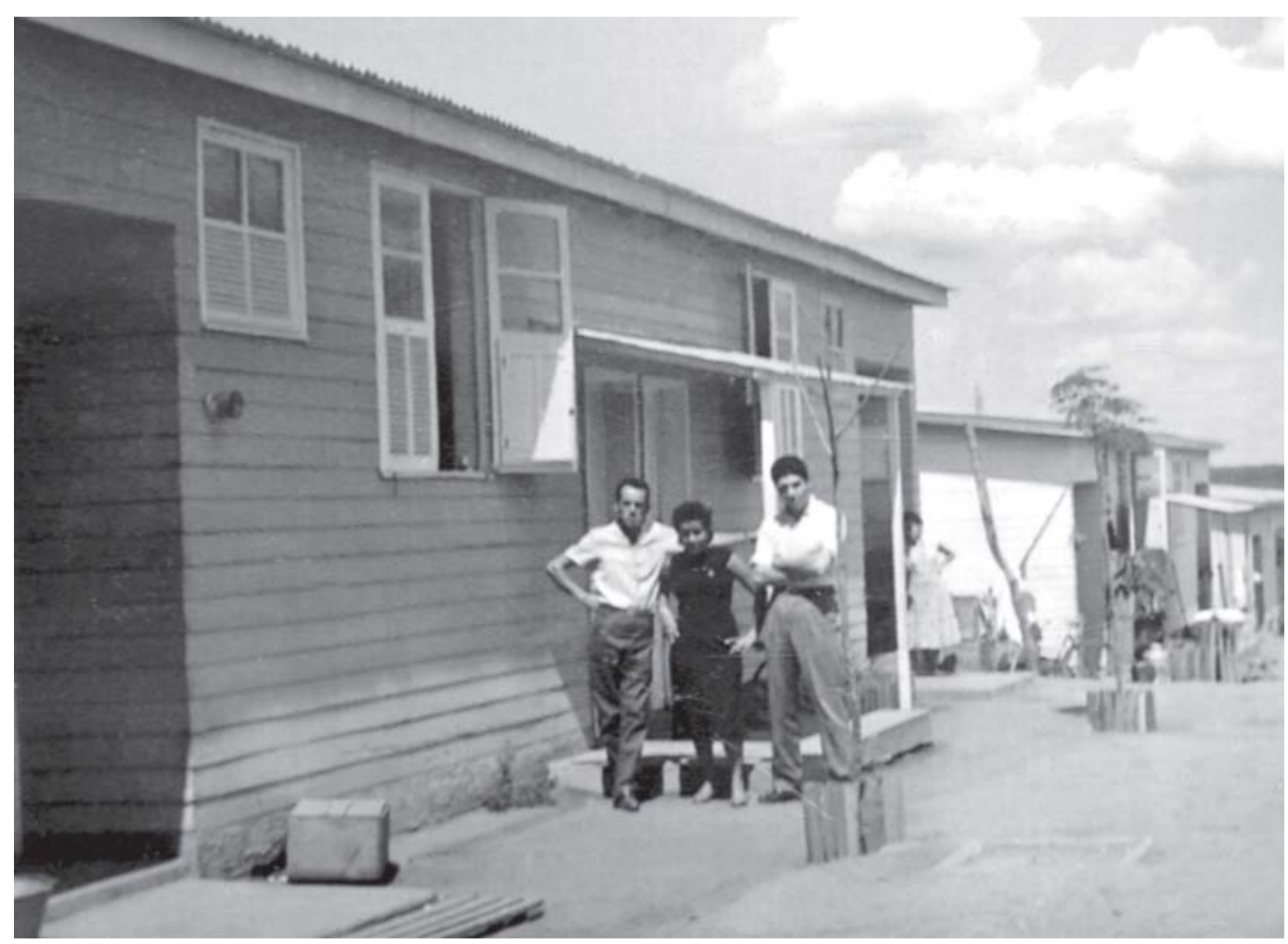

Figura 4: Residências dos médicos do Hospital Juscelino Kubitschek de Oliveira. Na foto, funcionários do hospital e doutor Edson Porto (à direita). (Arquivo pessoal de Edson Porto). 
Muitos médicos que escreviam para a Revista Goiana de Medicina compartilhavam do sentimento expresso por Rassi, que também se faz presente nos depoimentos de Edson Porto e Isaac Ribeiro. Amiúde os artigos da revista abordavam temas como o descaso do governo, o isolamento, a rotina, as péssimas condições de infra-estrutura, o analfabetismo e a pobreza da região em que viviam, identificando-os como os principais problemas enfrentados pela população interiorana em pleno anos 50 e apontando-os como reflexos do desequilíbrio entre litoral e interior. Assim, para esses médicos Brasília seria a solução para todos os problemas, e para muitos deles a localização desacertada da capital federal durante tanto tempo teria contribuído para a permanência e o aprofundamento das desigualdades.

O entusiasmo adiante das possibilidades de desenvolvimento que a construção de Brasília acarretaria para Goiás reflete-se em dois momentos marcantes: o 9o Congresso Médico do Brasil Central e Triângulo Mineiro e a solenidade de fundação da Faculdade de Medicina de Goiás. Nos trabalhos e discursos apresentados nas duas ocasiões, fica bastante evidente a participação dos médicos de Goiás na viabilização da nova capital, ao mesmo tempo que se percebe o impacto da construção de Brasília na vida desses profissionais, os quais ganham reconhecimento perante seus pares em âmbito nacional e incentivo para concretizarem seus projetos.

O 9o Congresso Médico do Brasil Central e Triângulo Mineiro realizou-se em Goiânia em 1958, enquanto as obras de construção de Brasília seguiam a todo o vapor. ${ }^{20}$ Destaco essa edição do Congresso em particular, pois nela foram proferidos muitos discursos importantes e repletos de referências ao trabalho médico que vinha sendo realizado no sítio da futura capital federal, exaltando-se a importância das atividades sanitárias que, uma vez concluídas, elevariam o interior à altura dos demais estados do país. Os resultados advindos desse certame, que ao final encaminhou uma moção referente ao saneamento de Brasília ao ministro da Saúde Mário Pinotti, mostram o engajamento dos médicos da região na luta em prol da interiorização da capital federal. Atentos à maneira como se desenrolavam os trabalhos de prevenção e saneamento da região, salientavam na moção a necessidade de permanente vigilância sanitária na área, para impedir a implantação e disseminação, no Planalto Central, da esquistossomose, moléstia de Chagas e outras doenças parasitárias ( 9 ํ Congresso..., 1958).

A instalação da Faculdade de Medicina de Goiás teria sido um ideal acalentado desde que foi fundada a AMG, em 1950. Entre as motivações para isso estavam, segundo Joffre Rezende, editor da Revista Goiana de Medicina, a inexistência de uma faculdade de medicina na região Centro-Oeste e o número insuficiente de médicos para atender à população na região (Rezende, 2001, fita 5, lado A). A maioria dos médicos, ao se formar, não optava pelo interior, fosse pela falta de estímulo e conforto, já que as condições de uma cidade no interior eram muito diferentes das de uma cidade litorânea (havia carência de luz elétrica, de água canalizada, de ambiente hospitalar etc.), ou pela falta de uma vida social mais intensa, e a ideia de fundar uma faculdade englobava também a intenção de formar médicos voltados para os problemas específicos da região:

a ideia da fundação de uma Faculdade de Medicina em Goiânia não é fruto de vaidade dos goianos, nem tão pouco desejo da classe médica de Goiás em obter empregos ou quaisquer 
outras vantagens próprias; somente o alto espírito de homens acostumados a lidar com os nossos moradores do sertão, conhecendo-os e, sobretudo às suas necessidades e o descaso com que são tratados pelos encarregados do destino da Nação, acomodados nas fofas poltronas e até mesmo nas brancas areias de Copacabana, levaram, nós, os médicos de Goiás, a pensar em um meio de formar profissionais capazes, distribuindo-os a todos os recantos do estado a fim de recuperar o homem rural, única maneira de dar a nossa Pátria uma estrutura social econômica à altura dos destinos que lhe estão reservados no Futuro ... (A Associação Médica..., 1955, p.64).

Inicialmente a faculdade tinha como objetivo contribuir para a fixação dos médicos no interior, constando entre suas normas a "obrigatoriedade de trabalhar no ano após sua formatura em pontos do Estado onde não exista médico na ocasião ..." (A Associação Médica..., 1955, p.63). No entanto, segundo Luiz Rassi, o projeto foi frustrado devido à falta de verba da universidade para remunerar esses estudantes. Ainda segundo ele, em contrapartida ao projeto, criaram-se campi avançados da universidade, onde os alunos faziam estágio de pelo menos um mês no interior, em locais como Porto Nacional, em Goiás (atualmente Tocantins), e Picos, no Piauí. O trabalho não se restringia a Goiás, estendendo-se a qualquer lugar onde houvesse uma base, ou seja, um hospital público.

Tal como a construção de Brasília, a Faculdade de Medicina representava, para os médicos goianos, melhorias de infra-estrutura para o interior do país, que até então, segundo eles, ficara esquecido dos planos de governo. Além disso, configurava-se como oportunidade de consolidar seu espaço de atuação, adquirindo com isso maior visibilidade, não apenas do trabalho que desenvolviam, mas também da região em que atuavam. Em seu depoimento, Rassi comenta que não desejava trocar Goiânia por Brasília, portanto entusiasmava-se com esse empreendimento em razão das inúmeras possibilidades que ele trazia para o estado e os médicos ali atuantes:

Do ponto de vista geral, Brasília representou o grande progresso que o Estado e toda a região do Centro-Oeste brasileiro sentiu com a sua construção. Houve desenvolvimento populacional, desenvolvimento econômico, desenvolvimento social. No desenvolvimento social nós podemos dizer, incluindo os médicos, houve um grande surto de desenvolvimento para a aplicação da medicina. Os médicos que inicialmente viviam no interior - aqui era interior tinham uma medicina prática, pouco científica, mais empírica ou mais prática. À medida que Brasília se consolidava como capital e a população aumentava, as exigências da própria população obrigavam os médicos a melhorar a sua capacitação profissional. Com isso, os médicos se especializaram, muitos permaneceram, outros se especializaram. ... De que forma: buscando conhecimento em outros lugares, outros centros médicos mais avançados, trazendo para esta região os conhecimentos mais atualizados. Então, houve um benefício incalculável na implantação de uma capital em nosso sertão de outrora, que hoje não é mais sertão ... (Rassi, 2006, fita 2, lado B).

\section{Considerações finais}

A pergunta que motivou a realização deste trabalho foi: qual terá sido o significado da construção, em pleno sertão do Brasil, em uma região historicamente associada a isolamento, doenças e pobreza, de uma capital federal que deveria espelhar o desenvolvimento e a modernidade de um país? À primeira vista a decisão de transformar em realidade um 
preceito constitucional tantas vezes adiado pode parecer paradoxal, mas ela mostra-se compreensível quando a consideramos no contexto dos anos 50, momento em que o problema das endemias rurais se afigurava como grande obstáculo e o comprometimento de Juscelino Kubitschek com o desenvolvimentismo tornava imprescindível superá-lo.

Configurando-se como desafio, a construção de Brasília em uma região marcada por problemas de isolamento e insalubridade tornava ainda mais 'apoteótico' o empreendimento. No entanto, para que esse 'sonho' se concretizasse ainda durante o mandato de Kubitschek, contou ele com a participação ativa dos goianos, que, desde a inclusão do preceito na Constituição de 1891, trabalharam para viabilizar a mudança da capital federal. Assim, seja através de periódicos que exaltaram as maravilhas de Goiás, cooperando politicamente na elaboração de decretos que facilitassem a transferência da capital, ou atuando efetivamente nas comissões de estudos do Planalto Central, os goianos demonstraram que, mais do que a consolidação de um desejo nacional, a nova capital representaria uma resposta aos anseios regionais. Tendo em vista os benefícios que ela traria para o Brasil Central como um todo, a questão mudancista mobilizava os goianos em todas as frentes possíveis, devendo-se ao seu empenho muito da rapidez com que Juscelino Kubitschek conseguiu concretizar sua meta-síntese.

A refletir o engajamento das elites goianas na concretização do projeto mudancista, os médicos goianos (ou partidários do ideal goiano) foram os personagens principais deste estudo. Atuantes nos sertões do Brasil, esses profissionais vislumbraram, na construção da nova capital, a oportunidade de ampliar seu espaço de atuação, até então restrito ao interior, e manifestaram, através dos artigos de uma revista médica, o grande significado daquela empreitada que estava sendo levada a cabo pelo governo federal. Conforme foi possível notar tanto nos artigos da Revista Goiana de Medicina como dos depoimentos, a transferência da capital para aquela região representou, para a elite médica daquele estado, uma projeção de seu trabalho a nível nacional, bem como a chance de concretizar projetos que até então eram apenas sonhos acalentados pelo círculo médico goiano, como por exemplo, a fundação da Faculdade de Medicina de Goiás.

Chama a atenção a grande mobilidade dos médicos do Brasil Central, os quais, apesar das dificuldades, encontravam brechas por onde circular tanto profissional como socialmente. Embora se queixassem do isolamento e do esquecimento a que estariam relegados, esses profissionais se atualizavam constantemente, participavam de congressos e realizavam pesquisas de interesse inclusive internacional, publicadas no periódico organizado por sua associação de classe, demonstrando-nos a necessidade de repensar a própria categoria 'médico sertanejo'. Movidos por idealismo e pelas perspectivas profissionais abertas pela construção de Brasília, eles se puseram na estrada, trilhando os caminhos mal traçados do Brasil Central e se tornaram pioneiros de um empreendimento histórico. Para esses 'pioneiros da poeira', tal como alguns desses médicos se autodenominam até hoje, por terem sido os primeiros a chegar na região onde seria erguida a nova capital, a construção de Brasília contribuiu para que Goiás deixasse de ser considerado sertão e passasse a ser apenas o 'sertão de outrora'.

Assim, destacar de um fundo aparentemente homogêneo a participação de Goiás na concretização do projeto de interiorização da capital, desde o início do século XX até a 
construção efetiva de Brasília, refletiu a necessidade de demonstrar que o discurso em prol da mudança carrega em si inúmeras vozes, nem sempre dissonantes. Na maioria das vezes elas são abafadas em determinadas interpretações históricas, diante da necessidade de generalização ou mesmo para exaltar a imagem, sempre bem descrita, do próprio presidente Juscelino Kubitschek, cujo espírito audacioso e empreendedor o teria levado - e não outro presidente - a efetuar a mudança. Por isso análises históricas que atentem para a importância regional se fazem relevantes, pois contribuem para uma compreensão mais ampla dos fenômenos sociais. No caso deste trabalho, pode-se afirmar que, além de constituir a região escolhida para assento da nova capital, Goiás, e mais precisamente a elite médica goiana, teve papel fundamental na concretização da transferência da capital para o Planalto Central.

\section{NOTAS}

${ }^{1}$ Primeira comissão de estudos organizada pelo governo com o objetivo de estudar a região do Planalto Central e demarcar as terras que futuramente abrigariam a nova capital federal. Constituída em 1892, era chefiada pelo astrônomo Luís Cruls e contava, entre seus membros, com geólogos, botânicos, astrônomos, farmacêuticos, médicos e militares, somando 22 pessoas. O Quadrilátero Cruls, resultado dos trabalhos efetuados por essa comissão, abrangia $14.400 \mathrm{~km}^{2}$.

${ }^{2}$ Segundo tal paradigma, também denominado neo-hipocrático, haveria uma relação intrínseca entre doença, ambiente e sociedade, a partir da qual era possível definir a salubridade de uma região, assim como identificar possíveis patologias a ela relacionadas (Ferreira, 2001).

${ }^{3}$ Segundo Kropf (2009), embora o relatório de Neiva e Penna tenha sido publicado no volume das Memórias do Instituto Oswaldo Cruz referente ao ano de 1916, existem atualmente indícios de que ele só teria sido editado quase dois anos depois. Sendo assim, não se pode afirmar que Miguel Pereira tenha proferido a famosa frase como fruto do impacto do relatório em questão, embora seja possível que ele já tivesse conhecimento desse documento antes mesmo de sua publicação. O importante, de acordo com a autora, é ressaltar que Miguel Pereira tinha conhecimento das condições precárias do interior antes mesmo da viagem realizada por Neiva e Penna.

${ }^{4} \mathrm{O}$ impacto gerado pela publicação do relatório de Neiva e Penna refletiu-se na organização do movimento sanitarista rural, que atuou como forte elemento de pressão sobre o Estado durante as duas primeiras décadas do século XX, desencadeando o processo de institucionalização da saúde pública no Brasil (Castro Santos, 1980; Hochman, 1993, 1998; Lima, Hochman, 1996, 2000, 2004).

${ }^{5}$ Com periodicidade mensal, Informação Goiana foi criada pelo médico e deputado goiano Antônio Americano do Brasil e pelo ex-membro da Comissão Cruls Henrique Silva.

${ }^{6}$ As informações acerca da mobilização goiana em torno do periódico em questão possuem caráter inédito e fazem parte da pesquisa que vem sendo desenvolvida na Casa de Oswaldo Cruz pela pesquisadora Dominichi Miranda de Sá, conforme artigo neste mesmo suplemento ("Uma interpretação do Brasil como doença e rotina: a repercussão do relatório médico de Arthur Neiva e Belisário Penna").

${ }^{7}$ Entre esses projetos estão o de Nogueira Paranaguá, apresentado em 1905, que propunha diretrizes práticas à execução da mudança; o de um engenheiro, que juntamente com dois deputados teria requerido ao Congresso Nacional o privilégio para a construção da capital mediante a concessão de alguns serviços em 1908; o do representante goiano Eduardo Sócrates, que em 1911 justificou um projeto autorizando a mudança mediante concessões de privilégios na exploração dos serviços urbanos; e o projeto Chermont, de 1919, que foi mais uma tentativa frustrada em prol da concretização do plano (Silveira, 1957).

${ }^{8}$ Além de seu presidente, general Poli Coelho, foram nomeados membros da Comissão: Cristovam Leite de Castro, Odorico Rodrigues de Albuquerque, Artur Eugênio Magarinos Torres Filho, Antonio Carlos Cardoso, Francisco Xavier Rodrigues de Souza, Luiz Augusto da Silva Vieira (vice-presidente), Jerônimo Coimbra Bueno, Jorge Leal Burlamaqui, Lucas Lopes, Luiz de Anhaia Melo e Geraldo H. de Paula e Souza.

${ }^{9}$ A Constituição estadual foi promulgada em julho de 1947. Em seu artigo 54 constava: "Localizada, neste Estado, na zona do Planalto Central, a futura Capital da República, ficará, na data da decretação 
da mudança, desmembrada automaticamente do território goiano, a área que, para esse fim, for delimitada pelo governo Federal até o limite máximo de cinqüenta e cinco mil km² ..." (Silveira, 1957, p.267).

${ }^{10}$ Além de Caiado de Castro, eram membros da comissão: Tasso da Cunha Cavalcanti, capitão Paulo Bosiso, coronel Aureliano Luiz de Faria, Jorge d'Escragnolle Taunay, Ademar Barbosa de Almeida Portugal, Flávio Vieira, João Castelo Branco, Paulo Assis Ribeiro, Valdir Niemeyer, coronel Júlio Américo dos Reis, engenheiro Jerônimo Coimbra Bueno (que já havia participado da comissão de estudos instituída no período Dutra), major Mauro Borges Teixeira e coronel Deoclécio Paulo Antunes.

${ }^{11}$ A Comissão ficou então composta por Aureliano Luiz de Faria, Ademar Barbosa de Almeida Portugal, Flávio Vieira, Paulo Assis Ribeiro, Júlio Américo dos Reis (antigos membros) e mais José Peixoto da Silveira (então Secretário da Saúde do estado de Goiás), Silvio Borges de Souza Mota, José Eurico Dias Martins, Fábio Macedo Soares Guimarães (que participou dos estudos de campo na comissão Poli Coelho), Lucídio Albuquerque, Augusto Sérgio da Silva, Felinto Epitácio Maia e Rubens d'Almeida Horta Porto.

${ }^{12}$ Ernesto Silva é médico formado pela Escola de Medicina e Cirurgia em 1946. Atuou como residente no Hospital Souza Aguiar e em 1948 trabalhou na enfermaria ortopédica do Hospital São Zacarias, transferindo-se depois para o setor de clínica pediátrica do hospital. Na década de 1950 afastou-se da clínica médica e assumiu o posto de diretor da Novacap (Silva, 2004, p.109-112).

${ }^{13}$ Esse Departamento disponibilizava ainda os serviços de vacinação antivariólica, antitífica-paratífica, Salk (paralisia infantil) e tríplice; um ambulatório de atendimentos gerais para os servidores da Novacap; uma equipe volante que percorria acampamentos, o Núcleo Bandeirante e as cidades-satélites, para efetuar vacinações; um Comando Sanitário, que inspecionava o comércio de gêneros alimentícios, restaurantes, bares e vendedores ambulantes; fiscalização de acampamentos e residências; e visitação mensal ao bordel do Núcleo Bandeirante, para exame médico das prostitutas (Silva, 2004, p.88-89).

${ }_{14}$ Ambos os serviços foram instalados em 1958. O Serviço de Tuberculose, sob direção do tisiologista Carlos Alberto Florentino, realizava o senso torácico na coletividade, distribuindo os resultados, chamando para o reexame, a becegeização, o controle dos focos de contágio e de seus comunicantes. Como auxílio ao seu trabalho, contou com o Serviço de Unidades Aéreas do Ministério da Saúde, sob a direção de Noel Nutels. Em 1959 a Novacap construiu um pequeno hospital com vinte leitos, para internação de tuberculosos que podiam se recuperar em breve tempo (Hospital do Tamboril). O Serviço Nacional de Lepra, dirigido por Almir de Andrade, examinava todos os casos suspeitos e tomava as medidas terapêuticas e sanitárias cabíveis (Silva, 2004, p.89-91).

${ }^{15}$ Joffre Marcondes de Rezende nasceu em 1921 em Minas Gerais e formou-se pela Faculdade de Medicina do Rio de Janeiro em 1950. Influenciado por um de seus colegas de turma, Francisco Ludovico de Almeida, decidiu trabalhar no interior, fixando-se em Goiânia.

${ }^{16}$ Com periodicidade trimestral, o periódico era composto por editorial, artigos originais, noticiário (com informações sobre congressos, jornadas e atividades da própria associação), resumos de trabalhos (inclusive estrangeiros), sessões clínico-patológicas, página literária e outras seções esporádicas, como as de temas da atualidade e de correspondência.

${ }^{17}$ Segundo Joffre Rezende (2001, fita 3, lado B), Philip Marsden, professor inglês de medicina tropical, escrevia resumos dos artigos da Revista Goiana de Medicina e os enviava para o Tropical Diseases Bulletin, de Londres.

${ }^{18}$ A instalação dessa circunscrição, sob a direção de João Leão da Motta, contou com a ajuda da Novacap. Tratava-se de um posto pioneiro que funcionava em barraca de lona e promovia vacinação anti-amarílica, exame e tratamento do tracoma, campanha anti-helmíntica, exames e pesquisas de laboratório, desinsetização de casas, alojamentos e acampamentos, além de permanecer vigilante na erradicação do barbeiro das regiões vizinhas (Silva, 2004, p.89).

${ }^{19} \mathrm{Na}$ Cidade Livre se concentravam comércio, indústria e serviços. Por seu caráter de núcleo provisório, as construções deveriam ser de madeira, para que o local fosse destruído tão logo a nova capital estivesse edificada. Seu nome advém da condição de isenção de impostos e taxas para todas as atividades ali desenvolvidas (Ceballos, 2005, p.86-94).

${ }^{20}$ Esses congressos eram uma oportunidade de interação entre os médicos do interior, médicos provenientes dos grandes centros e o governo. Eram considerados "espaços importantes de representação e afirmação sócio-profissional dos clínicos do interior ..." (Kropf, 2006, p.444). O primeiro deles aconteceu em 1947, na cidade de Uberaba, e esteve restrito a profissionais do Triângulo Mineiro. Em 1951 o evento incluiu os estados de Goiás e Mato Grosso, transformando-se então em Congresso Médico do Triângulo Mineiro e Brasil Central (Porto, Porto, 1970, p.118). 


\section{REFERÊNCIAS}

A ASSOCIAÇÃO MÉDICA...

A Associação Médica de Goiás e a Faculdade de Medicina. Revista Goiana de Medicina, Goiania, v.1, n.1, p.62-64. 1955.

BOJUNGA, Cláudio.

$J K$ : o artista do impossível. Rio de Janeiro: Objetiva. 2001.

BOMENY, Helena.

Utopias de cidade: as capitais do modernismo. In: Gomes, Ângela de Castro (Org.). O Brasil de JK. Rio de Janeiro: Ed. FGV, p.201-223. 2002.

BRASIL.

Departamento Administrativo do Serviço Público Federal. Serviço de documentação. O relatório técnico sobre a nova capital da República. Rio de Janeiro: Departamento de Imprensa Nacional. 1957.

BRASIL.

Lei n.2874 de 19 de setembro de 1956. Dispõe sobre a mudança da capital federal e dá outras providências. Disponível em:

<http://www6.senado.gov.br/sicon/

PreparaPesquisa.action?tipoPesquisa=3>. Acesso em: 07 fev. 2007. 1956

BRASIL.

Decreto n.38281 de 9 de dezembro de 1955.

Transforma a Comissão de Localização da Nova Capital em Comissão de Planejamento da Construção e da Mudança da Capital Federal e dá outras providências. Disponível em: <http://www6.senado.gov.br/sicon/ PreparaPesquisa.action?tipoPesquisa=3>. Acesso em: 07 fev. 2007. 1955.

BRASIL.

Lei n.1803 de 5 de janeiro de 1953. Autoriza o Poder Executivo a realizar estudos definitivos sobre a localização da nova capital da República. Disponível em: <http:// www6.senado.gov.br/sicon/

PreparaPesquisa.action?tipoPesquisa $=3>$. Acesso em: 07 fev. 2007. 1953.

BRASIL.

Comissão de Estudos para Localização da Nova Capital. Relatório técnico.

v.33. Comissão de Estudos para Localização da Nova Capital. Rio de Janeiro: s.n. 1948.

BRASIL.

Constituição, 1946. Constituição da República dos Estados Unidos do Brasil de 18 de setembro de 1946. Disponível em: <http://

www6.senado.gov.br/sicon/

PreparaPesquisa.action?tipoPesquisa=3>. Acesso em: 07 de fevereiro defev. 2007. 1946.
BRASÍLIA...

Brasília: cidade humana. O Cruzeiro, Rio de Janeiro, ano 32, n.24. 1960.

CARVALHO, Áttila Gomes de; CASTRO, Aloysio de Almeida e.

Realizações da Circunscrição Goiás do DNERu durante o ano de 1956. Revista Goiana de Medicina, Goiania, v.3, n.2, p.99-118. 1957.

CARVALHO, Áttila Gomes de; VERANO,

Ottoni Torres.

Contribuição ao conhecimento da distribuição geográfica dos triatomídeos domiciliários e de seus índices de infecção natural pelo Schizotrypanum cruzi, na região do Planalto Central (Retângulo de Cruls), Estado de Goiás, Brasil. Revista Goiana de Medicina, Goiania, v.2, n.3, p.181-200. 1956.

CASTRO, Cristóvão Leite de.

A mudança da capital capital do país. Revista Brasileira de Geografia, Rio de Janeiro, ano 10, n.3-4, p.117-119. 1948.

CASTRO SANTOS, Luiz Antonio.

Estado e saúde pública no Brasil (1889-1930). Dados, Rio de Janeiro, v.23, n.2, p.237-250. 1980.

CEBALlOS, Viviane Gomes de.

'E a história se fez cidade...': a construção histórica e historiográfica de Brasília, 2005. Dissertação de (Mestrado) - Instituto de Filosofia e Ciências Humanas, Universidade Estadual de Campinas, São Paulo. 2005.

CORBISIER, Roland.

Brasília e o desenvolvimento nacional. Rio de Janeiro: Iseb. 1960.

COSTA, Lúcio.

Relatório do Plano Piloto de Brasília. Brasília: s.n. 1991.

COUTO, Ronaldo Costa.

Brasília Kubitschek de Oliveira. Rio de Janeiro: Record. 2006.

CRULS, Luiz. Relatório Cruls: relatório da Comissão Exploradora do Planalto Central do Brasil. Brasília: Senado Federal. 2003.

CUNHA, Euclides.

Os sertões. 39.ed. Rio de Janeiro: Livraria Francisco Alves Editora. 1997.

EDITORIAL.

Revista Goiana de Medicina, Goiania, v.1, n.1, p.1. jul-set. 1955.

FERREIRA, Luís Otávio.

Uma interpretação higienista do Brasil Imperial. In: Heizer, Alda; Videira, Antonio 
Augusto Passos (Org.). Ciência, civilização e império nos trópicos. Rio de Janeiro: Access. p.207-223. 2001.

GUIMARÃES, Fábio de Macedo Soares. O Planalto Central e o problema da mudança da capital do Brasil. Revista Brasileira de Geografia, Rio de Janeiro, ano 11, n.4, p.471-536. 1949.

HOCHMAN, Gilberto.

A era do saneamento: as bases da política de saúde pública no Brasil. São Paulo: Hucitec. 1998.

HOCHMAN, Gilberto.

Regulando os efeitos da interdependência: sobre as relações entre saúde pública e construção do estado (Brasil 1910-1930). Estudos Históricos, Rio de Janeiro, v.6, n.11, p.40-61. 1993.

KROPF, Simone Petraglia.

Doença de Chagas, doença do Brasil: ciência, saúde e nação (1909-1962). Tese (Doutorado) Instituto de Ciências Humanas e Filosofia, Universidade Federal Fluminense, Niterói. 2006.

KROPF, Simone Petraglia.

Doença de Chagas, doença do Brasil: ciência, saúde e nação (1909-1962). Rio de Janeiro: Editora Fiocruz. 2009.

KUBITSCHEK, Juscelino.

Porque construí Brasília. Brasília: Senado Federal, Conselho Editorial. 2006.

KUBITSCHEK, Juscelino.

Programa de saúde pública do candidato Juscelino Kubitschek. São Paulo: L. Nicollini. 1955.

LIMA, Nísia Trindade.

Viagem científica ao coração do Brasil: notas sobre o relatório de expedição de Arthur Neiva e Belisário Pena a Bahia, Pernambuco, Piauí e Goiás (1912). Revista da Fundação Museu do Homem Americano, Rio de Janeiro, v.1, n. 3, p.185-215. 2003.

LIMA, Nísia Trindade.

Um sertão chamado Brasil: intelectuais e representação geográfica da identidade nacional. Rio de Janeiro: Revan. 1999.

LIMA, Nísia Trindade; HOCHMAN, Gilberto. Pouca saúde e muita saúva: sanitarismo, interpretações do país e ciências sociais. In: Armus, Diego; Hochman, Gilberto (Org.). Cuidar, controlar, curar: ensaios históricos sobre saúde e doença na América Latina e Caribe. Rio de Janeiro: Editora Fiocruz. p.493-533. 2004.

LIMA, Nísia Trindade; HOCHMAN, Gilberto. 'Pouca saúde, muita saúva, os males do Brasil são...': discurso médico-sanitário e interpretação do país. Ciência \& Saúde Coletiva, Rio de Janeiro, v.5, n.2, p.313-332. 2000.

LIMA, Nísia Trindade; HOCHMAN, Gilberto. Condenado pela raça, absolvido pela medicina: o Brasil descoberto pelo movimento sanitarista da Primeira República. In: Maio, Marcos Chor; Santos, Ricardo Ventura (Org.). Raça, ciência e sociedade. Rio de Janeiro: Fiocruz. p.23-40. 1996.

LIMA, Nísia Trindade; HOCHMAN, Gilberto; FONSECA, Cristina M.

A saúde na construção do Estado Nacional no Brasil: reforma sanitária em perspectiva Histórica. In: Lima, Nísia Trindade; Gerschman, Silvia; Edler, Flávio C.; Suárez, Julio M. (Org.). Saúde e Ddemocracia: história e perspectivas do SUS. Rio de Janeiro: Editora Fiocruz. p.27-58. 2005.

MOREIRA, Vânia Maria L.

Brasília: a construção da nacionalidade - um meio para muitos fins. Vitória: Edufes. 1998.

NEIVA, Arthur; PENNA, Belisário.

Viagem científica pelo norte da Bahia, sudoeste de Pernambuco, sul do Piauí e de norte a sul de Goiás. Brasília: Senado Federal. Ed. fac-similar. 1999.

9o CONGRESSO...

9o Congresso Médico do Brasil Central e Triângulo Mineiro. Revista Goiana de Medicina, Goiania, v.4, n.3, p.263-289. 1958.

OLIVEIRA, Ricardo.

Euclides da Cunha, Os Sertões e a invenção de um Brasil profundo. Revista Brasileira de História, São Paulo, v.22, n.44, p.511-537. Dossiê Viagens e Viajantes. 2002.

PEREIRA, Miguel.

O Brasil é ainda um imenso hospital: discurso pronunciado pelo professor Miguel Pereira por ocasião do regresso do professor Aloysio de Castro, da República Argentina, em outubro de 1916. Revista de Medicina, São Paulo, v.7, n.21, p.3-7. 1922.

PORTO, Calil; PORTO, Celmo Celeno. História do megaesôfago nos congressos médicos do Brasil Central. Revista Goiana de Medicina, Goiania, v.16, n.1-2, p.117-136. 1970.

PORTO, Edson.

Depoimento. Rio de Janeiro: Casa de Oswaldo Cruz. Depoimento concedido ao Projeto Brasil Imenso Hospital: Ideias e Políticas de Saúde na Invenção do País. 2006.

RASSI, Luiz.

Depoimento. Rio de Janeiro: Casa de Oswaldo Cruz. Depoimento concedido ao Projeto Brasil Imenso Hospital: Ideias e Políticas de Saúde na Invenção do País. 2006. 
REZENDE, Joffre Marcondes de.

Depoimento. Rio de Janeiro: Casa de Oswaldo Cruz. Depoimento concedido ao Projeto

História da Pesquisa Sobre a Doença de Chagas no Brasil. 2001.

RIBEIRO. Isaac Barreto.

Depoimento. Rio de Janeiro: Casa de Oswaldo Cruz. Depoimento concedido ao Projeto Brasil Imenso Hospital: Ideias e Políticas de Saúde na Invenção do País. 2006.

RIBEIRO, Isaac Barreto.

Profilaxia da doença de Chagas em Brasília.

Revista Goiana de Medicina, Goiania, v.3, n.3, p.197-202. 1957.

ROSAS, Roberta Jenner.

Do paraíso ao grande hospital: dois olhares da ciência sobre o sertão (Goiás - 1892-1912). Dissertação (Mestrado) - Universidade de Brasília, Brasília. 1996.

SILVA, Ernesto.

O militante da esperança e a história de Brasília. Brasília: Editora Brasília. 2004.

SILVEIRA, Peixoto da.

A nova capital: por que, para onde e como mudar a capital federal. Rio de Janeiro: Pongetti. 1957.

VARNHAGEN, Francisco.

A questão da capital: marítima ou no interior? Viena: Imp. do filho de Carlos Gerald. Ed. do autor. 1877. 